\title{
UnCOMmon LAW: THE PRIVATIZATION OF DisPUTE Resolution ACROSS THE POND
}

\author{
Chris A. Carr" and Michael R. Jencks"*
}

\section{I.INTRODUCTION}

The common law is the best and most common birth-right that the subject hath for the safeguard and defence, not only of his goods, lands and revenues, but of his wife and children, his body, fame and life also.'

The common law remains one of the most important legacies we Americans received from our shared history and roots with England, and a birthright our citizens share with those of the United Kingdom. Not only did the common law serve as the model for our own jurisprudence, but generations of American lawyers, including many of our founding fathers, early presidents, and most eminent early jurists, were trained on Lord Coke's Commentary on Littleton and Reports $s^{2}$ and understood and embraced Lord Coke's admonition to let not cases be committed:

"to slippery memory, which seldom yieldeth a certain reckoning. In troth, reading, hearing, conference, meditation, and recordation are necessary.",

So it is with more than a little interest - and concern - that many of us on this side of the Atlantic are following the civil justice reform and alternative dispute resolution (A.D.R.) movement in England. The proffered motivations - court congestion, delay, cost, and the like - are the same ones that launched our own

\footnotetext{
* Assistant Professor of Business Law and Public Policy, California Polytechnic State University - San Luis Obispo, California.

"* Principal, Jencks Law Group, Arroyo Grande, California.

1 Sir Edward Coke, quoted in Catherine Drinker-Bowen, The Lion and the Throne: the Life and Times of Sir Edward Coke (London, Hamish Hamilton, 1957) at p.509

2 Catherine Drinker-Bowen, ibid at pp.513-514 [hereafter BOWEN].

3 Sir Edward Coke, ibid at p.506.
} 
civil justice reform and A.D.R. movement in the 1970s. The resulting changes, however, have exacted a heavy toll on the American legal system and quality of justice, particularly by eroding our common law foundation in favour of the privatization of commercial dispute resolution.

The common law, and how it develops principles for allocating risk and deciding business and commercial disputes through a body of reported public decisions, has provided a framework for governing commercial trade and commerce that many countries have adopted today. ${ }^{4}$ Scholars from Harvard University and the University of Chicago even credit the common law as a reason why certain countries develop at a more advanced rate than others. ${ }^{5}$ The common law, with its tradition of stability and predictability, is often cited as an important factor why companies are attracted to particular countries and states to do business. ${ }^{6}$ But perhaps the common law's most salient feature and key to its creative genius has been its acceptance of change and evolution, that "the common law could not stand still - it must be developed to respond to the demands of justice in a living society"7 by the creative development of legal principles derived from "judges of the past searching the casebooks for just

${ }^{4}$ See Ray August, International Business Low (Prentice Hall, ${ }^{\text {nd }}$ ed., 1997), at p. 42 (map depicting the distribution of the world's legal systems).

s See "The Law of the Market" The Economist, (19 April, 1997) at p.78. See also, La Porta, Lopez-de-Silanes, Shleifer \& Vishny, Law and Finance, National Bureau of Economic Research, N.B.E.R. Working Paper 5661 (July, 1996) and La Porta, Lopez-de-Silanes, Shleifer \& Vishny, Legal Determinants of External Finance, National Bureau of Economic Research, N.B.E.R. Working Paper 5879 (January, 1997) (on file with the authors).

${ }^{6}$ See Robert Stewart, Bermuda: An Economy Which Works (Island Press Ltd., 1997) (pointing out that one of the major reasons why international companies are attracted to Bermuda is its English common law system and the objective, public decisions rendered by the British Judicial Committee of the Privy Council). Further, Donald Conlon and Daniel Sullivan note that a key reason why many companies incorporate in the state of Delaware is because of its:

" 200 plus years of case law. In its breadth and depth, this body of law goes further than similar bodies of law in other states toward meeting corporate needs for certainty and predictability. Organization theorists have long recognized the importance of reducing uncertainty by controlling or managing elements of the external environment, such as the legal environment "(citations omitted)

in Donald E. Conlon \& Daniel P. Sullivan, "Examining the Actions of Organizations in Conflict: Evidence from the Delaware Court of Chancery" Acad. of Mgmt. J., June, 1999, at p. 320

7 Robert Goff, "Lord Denning - A Memoir" [1999] Denning L. J. xxiii at p.xxv. 
solutions to new problems." ${ }^{\text {, }}$ This genius is well illustrated by the contribution of the common law to the rapidly changing field of intellectual property:
"[T]he common law has emerged as a source of protection for intellectual property rights throughout this century whenever statutory protection for new forms of media were still evolving. This phenomenon results from the relationship between communication technologies, which are dynamic and often difficult to anticipate, and statutes, which traditionally have been adopted only in reaction to such changes ... [I]n cases in which statutory protection may not readily apply to new technologies, intellectual property owners have repeatedly and successfully resorted to common law theories for legal solutions to new problems."

However, notwithstanding the common law's undeniable contributions to and facilitation of trade and commerce, the common law as a jurisprudential system for developing commercial precedent in the United States is under siege by a purported reform movement bent on implementing "managerial justice" by largely privatizing business and commercial dispute resolution. Privatization is accomplished through a variety of procedural tools including private and judicially mandated A.D.R., vacatur, selective publication, depublication, filings under seal, confidential settlements, and even the arrival of corporate megafirms. The resulting irony is that as commercial dispute resolution is increasingly privatized, the growth and development of the very body of law which has traditionally served business and commerce so well is being stunted, if not stopped.

We explain below how and why we believe the development of a contemporary body of commercial law in the United States is being thwarted and distorted through these various privatization processes in the earnest hope that highlighting these mistaken policies will assist U.K. and primarily English readers in apprising their own civil justice reform initiatives and in ensuring that those reforms do not result in throwing the common law "baby" out with the bath water.

8 The Hon. Justice Michael Kirby A.C. C.M.G., "Lord Denning and Judicial Activism" [1999] Denning L. J. 127 at p.145.

"Bruce P. Keller, "Condemned to Repeat the Past: The Reemergence of Misappropriation and Other Common Law Theories of Protection for Intellectual Property Rights" 11 Harv. J. L. \& Tech. 401 at p.403 (1997). 


\section{THE DENNING LAW JOURNAL}

\section{II.THE ROLE OF THE COMMON LAW IN AMERICAN BUSINESS DISPUTE RESOLUTION}

A foundational principle of the American body politic is that citizens and businesses are provided with access to legal and political processes, and that these processes are subject to public scrutiny. However, the widespread privatization of business dispute resolution limits the very development of such a system. Further, it distorts the development of a contemporary body of commercial law. Before courts are allowed or encouraged to become even more removed from such processes, it is helpful to revisit the critical role that the common law system of precedent plays in the development and growth of commercial law.

\section{(a) Precedent Defined}

Precedent is:

"an adjudged case or decision of a court, considered as furnishing an example or authority for an identical case afterwards arising or a similar question of law." 10

Precedent is implemented by the doctrine of stare decisis -- the protocol that courts should follow precedent in deciding cases and which has been in place for centuries, " and remains "the everyday working rule of our law." $"$ In American law schools, through the use of the case method, students are taught how to identify and use precedent.

Moreover, this training and process does not end upon graduation from law school. Young litigators soon learn that judges -- at least the good ones -- do, in fact, "exam and compare" precedent, ${ }^{13}$ and that the modification and development of precedent depends upon a change in the holdings of individual courts about specific disputes. ${ }^{14}$ When this process is properly implemented and followed, the body of commercial law does indeed:

${ }^{10}$ Black's Law Dictionary $1176\left(6^{\text {th }}\right.$ ed. 1990).

11 Sir William Blackstone, Commentaries I.62-63.

12 Benjamin N. Cardozo, The Nature of the Judicial Process (Yale University Press, 1921) at p. 20 .

3 Ibid.

14 Ibid at pp. 23-25 


\section{UNCOMMON LAW}

"stand as a monument slowly raised, like a coral reef, from the minute accretions of past individuals, of whom each built upon the relics which his predecessors left, and in his turn left a foundation upon which his successors might work." 15

(b) Precedent -. Why is it Used by Courts?

Courts use precedent for a variety of reasons. For example, prior judicial decisions serve as the "public record of the 'unwritten law,' customs and legal traditions, acquiring both their meaning and authority from recognition as part of the collective wisdom or reason."

"precedent helps establish a smooth transition between the accumulated experience of the past, evidenced by judicial decisions, and the present, to which the reasoning of the prior decision is applied, unless the present court determines that the prior court's reasoning was in error." 17

Courts also use precedent not because it represents society's collective wisdom or reasoning, but because of the very authority of the judiciary. ${ }^{18}$ Under this view, the judiciary, as the sovereign, has the authority and right to establish a legal framework by which rules can be known, legal consequences can be predicted, and public expectations can thereby be protected. ${ }^{19}$

\section{(c) How Do Courts Use Precedent in Business Cases?}

Courts use precedent in business cases in a variety of ways. First, they look to precedent to help resolve the dispute at hand. ${ }^{20}$ Professor Melvin Eisenberg writes:

"Complex societies characteristically need an institution that can conclusively resolve disputes deriving from a claim of right based on the application, meaning, and implications of the .

15 Learned Hand, "Review of Judge Cardozo's The Nature of the Judicial Process" 35 Harv. L. Rev. 479 at p.479 (1922)

${ }^{16}$ Mark D. Hinderks \& Steve A. Leben, "Restoring the Common in the Law: A Proposal for the Elimination of Rules Prohibiting the Citation of Unpublished Decisions in Kansas and the Tenth Circuit" 31 Washburn. L. J. 155 at p.170 (1992).

17 Ibid.

18 Ibid.

19 Ibid.

20 Melvin Aron Eisenberg, The Nature of the Common Law (Harvard Univiversity Press, 1988) at p.4. 


\section{THE DENNING LAW JOURNAL}

society's existing standards. In our society that institution is the courts, and the resolution of such disputes is accordingly a central function of our courts. This centrality is manifested in a variety of ways. To begin with, courts in our society are structured to be fundamentally passive. Unlike a legislature, a court may not properly initiate action on its own motion but may act only when set in motion by a party with a claim.

Correspondingly, a court is limited to action that is responsive to the claim made. The kinds of claims the court may properly act upon are also limited. The claim normally must be contested that is, the subject of a dispute. The claimant normally must assert that the respondent has either infringed (or threatens to infringe) upon his rights, or is otherwise at fault in a manner that sufficiently involves the claimant's interest to render it appropriate for him to make a claim whose disposition turns on that fault. The claim must be based on a standard that relates to [business norms] rather than, say, on an artistic standard. The standard on which the claim is based must rise to a certain level of significance, in terms of either the seriousness of the injury that typically results from its violation or the importance of the norm or policy that it reflects." 21

Second, courts use precedent to further enrich the supply of legal rules that govern business disputes. ${ }^{22}$ Eisenberg further writes:

"Our society has an enormous demand for legal rules that actors can live, plan, and settle by. The legislature cannot adequately satisfy this demand. The capacity of the legislature to generate legal rules is limited, and much of that capacity must be allocated to the production of rules concerning governmental matters, such as spending, taxes, and administration; rules that are regarded as beyond the courts' competence, such as the definition of crimes; and rules that are best administered by a bureaucratic machinery, such as the principles for setting the rates charged by regulated industries. Furthermore, legislatures are normally not staffed in a manner that would enable them to 
perform comprehensively the function of establishing law to govern action in the private sector. ${ }^{, 23}$

Thus, the following question arises: are today's courts in the United States being utilized to their fullest potential in developing and refining our body of contemporary commercial law? As discussed below, the answer is, unfortunately, no. But before we turn to this question in detail, we first address the important point of how business cases in the United States have changed over the years and how those changes have challenged our courts' ability to efficiently resolve such disputes.

\section{III.The Changing Nature of Business Cases}

Our society has changed over the years, as has the nature of our business transactions and resulting business disputes that our courts are being asked to resolve.

(a) Secondary Rights and Increased Case Complexity

In recent years in the United States, there has been a proliferation of

"secondary" or redundant rights in many types of business cases. This has in turn significantly increased the complexity of many business disputes. By way of example, consider the following.

Years ago a licensor who licensed a patent to a licensee and then discovered that the licensee was misusing the patent was likely to allege that the right that had been violated was the licensing agreement (i.e., it was breached). Today, that same case will see a plethora of secondary rights come into play based on contract law, federal patent law, and unfair competition law. Specifically, as in the past the licensor's complaint will allege a cause of action for breach of the licensing agreement. But it will also allege a cause of action for infringement -in part to attempt to obtain the benefit of treble damages versus standard breach of contract damages. Also, the licensee will bring its own counterclaim for unfair competition-antitrust violations.

Similarly, twenty years ago a dispute between a law firm and its client over fees, to the extent that unpaid fees were even pursued, normally consisted of the law firm filing a complaint for breach of contract with the client in turn filing an answer that alleged a few straightforward affirmative defenses. Discovery in the case was clean and simple, as were the legal issues. Today, that same dispute results in the client not only filing an answer, but a counterclaim for

${ }^{23}$ Ibid at pp.4-5. 


\section{THE DENNING LAW JOURNAL}

professional negligence (usually for leverage purposes), and the cost and complexity of the case are thereby significantly increased.

In summary, these secondary rights often transform what used to be a relatively straightforward business case for the court to decide into the exact opposite. $^{24}$

\section{(b) Increased Internationalization}

Not only has there been a proliferation of secondary rights and case complexity, but in recent years we have witnessed the emergence and development of a truly global economy. ${ }^{25}$ The United States is no longer a country in which local manufacturers use local materials and labour to create a product for sale only in a local market. Instead, many products are made for a national or even international market. It is not uncommon for manufacturers to:

\section{"obtain raw materials or parts in one country, perform subassembly in another country, [with] final assembly [occurring] in yet another, then deliver [the] products "just in time' to customers in several countries. ${ }^{, 26}$}

This phenomenon has presented difficult and complex choice of forum, choice of law, discovery, and judgment enforcement issues for our courts, especially our state courts who are often unfamiliar with such issues. ${ }^{27}$

\section{(c) Increased Speed}

Many of today's business transactions and markets, especially in an era of electronic commerce, move faster than ever before. Take Web entrepreneurs as an example. In the past such entrepreneurs did not normally think in terms of the patentability of their business ideas and inventions. ${ }^{28}$ Yet the market is now forcing them to do so, and they are discovering that it can take eighteen months just for a patent to be issued, ${ }^{29}$ let alone litigate any related ownership dispute in

\footnotetext{
24 See also, Jeffrey W. Stempel, "A More Complex Look at Complexity" 40 Ariz. L. Rev. 781 (1998) ("[I]t seems fair to conclude that there has been major growth ... of complex cases."[at p.819]).

${ }^{25}$ See Schaffer, Earle \& Agusti, International Business Law and its Environment $\left(3^{\text {rd }}\right.$ ed., West Publishing) at pp.4-6.

26 Byron Acohido, "Expansion Express--Airlines, Air-Freight Companies Enter High Stakes Arena of Global Delivery" Seattle Times, ( $3^{\text {rd }}$ June, 1990), at E1.

27 See, e.g., Schaffer, Earle \& Augusti, supra n.25 at pp. $105-130$

28 See Wendy R. Leibowitz, "Lawyers and Technology: Patents and E-Business" NAT'LL.J., (14 $4^{\text {th }}$ June, 1999) at A19.

29 Ibid.
} 


\section{UNCOMMON LAW}

the courts. By the time such litigation is resolved, the cyber-market place will have changed several times over, thereby often making the end-result of the litigation irrelevant. ${ }^{30}$

In short, courts sometimes find it difficult to keep up with a market-place that demands expedited resolutions. ${ }^{31}$

\section{IV.The Flight of Businesses CaSes to Private A.D.R.}

Based on business behaviour itself, it appears that voluntary resort to private A.D.R. is an increasingly frequent impediment to fully developing and refining our body of contemporary commercial law: for the past several decades businesses have been increasingly fleeing to private A.D.R. to resolve their disputes. $^{32}$

The decision by parties to a dispute to submit their dispute to A.D.R., whether by a previously negotiated A.D.R. clause in a contract or an agreement to submit to A.D.R. when the dispute arises, is generally a private and elective decision but nevertheless results in the diversion and unavailability of that dispute from a public resolution. Indeed, the national policy favouring arbitration is so strong that the United States Supreme Court has concluded that Congress intended in passing the Federal Arbitration Act to withdraw the power of the States to require a judicial forum for the resolution of claims which the

30 Ibid.

${ }^{31}$ To speed up business dispute resolution, many American courts have implemented "rocket dockets" or "fast-track" systems. See, e.g., Carrie E. Johnson, "Rocket Dockets: Reducing Delay in Federal Civil Litigation" 85 Cal. L. Rev. 225 (1997). However, the efficacy and quality of these systems is questionable $i b i d$ at pp.238-254.

${ }^{32}$ In the early 1980s several Fortune 500 companies founded the Center for Public Resources ("C.P.R.") Institute for Dispute Resolution to explore private dispute resolution as an alternative to litigation when involved in a dispute with each other. A "C.P.R. Pledge" was created in which member companies promised to explore A.D.R. before litigating with each other. C.P.R obtained 50 signatories to that Pledge in 1983. By mid-1999, that number had grown to 4,000. See <http://www.cpradr.org/corppldg.htm $>$. Recent surveys also confirm an increase in the use of private A.D.R. by American business. For example, a 1994 survey conducted by Arthur Anderson LLP General Counsel and Corporate Legal Times found that fifty percent of those surveyed had used A.D.R. within the last year - a seventy-five percent increase in A.D.R. use over the prior year. See "News From Around the States: Survey Shows Increase in Corporate ADR Use" 6 World Arb. \& Med. Rep. 145 at p. 145 (1995) Private A.D.R. providers also report a significant increase in business. For example, the total number of private arbitrations and mediations handled through the American Arbitration Association ("A.A.A.") alone has nearly doubled in the past decade, to a projected 90,000 in 1998. See Carolyn Kleiner, "The Action Out of Court" U. S. News \& World Report, $29^{\text {th }}$ March, 1999 at p. 90 


\section{THE DENNING LAW JOURNAL}

contracting parties agreed to resolve by arbitration ${ }^{33}$ The consequences of the removal of these cases has consequences for the parties and public alike. For example, "arbitrators ... are not necessarily bound by earlier decisions of other arbitrators in the same case ${ }^{3.34}$ nor does an arbitration award have any collateral estoppel effect in favour of non-parties to an arbitration. ${ }^{35}$

In this section, we discuss some of the primary reasons for this flight to private A.D.R. in the United States, and, more importantly, why many of these reasons may be based more on misconception than fact.

\section{(a) Perceived Court Congestion and Delay}

For those who advocate an increased role for A.D.R. in resolving business disputes, the point is often made that the courts are congested, rife with delay and inaccessible due to a "litigation explosion." One commentator has noted that with the:

"excessive delays and exploding caseloads of the civil courts, many disputants view traditional litigation as unable to meet their conflict resolution needs. More and more parties are turning away from the judicial system and are resorting to private dispute resolution firms." 36

The cause of this so-called litigation explosion has been the subject of intense debate in the United States. Some proffered reasons include the growing diversity and size of the American population; a heightened level of litigiousness among Americans; an increase in the number of judicially and statutorily created rights and a broadening of the definition of the class of people entitled to enforce those rights; expanded discovery; excessive lawmaking; an increase in crime and criminal prosecutions (especially drug-related offences); and so on. But what is interesting to note is that to the extent that such an explosion has occurred, there is no evidence that suggests that it has

${ }^{33}$ See Southland Corp. v. Keating, 465 U.S. 1; 79 L.Ed. 2d 1; 104 S. Ct. 852 (1984) (reversing a California Supreme Court case (Keating v. Superior Court, 31 Cal.3d 584; 183 Cal. Rptr. 360; 645 P.2d 1192 (1982) which had found that the state legislature had intended claims under the California Franchise Investment Act (Corporations Code $\$ \S 3100$ et seq.) to be limited to judicial enforcement).

34 Broughton v. CIGNA Health Plans of California, 21 Cal. $4^{\text {th }} 1066$ at $1081 ; 90$ Cal. Rptr. 2d 334; 988 P.2d 67, 77 (1999).

${ }^{35}$ Vandenberg v. Superior Court, 21 Cal. $4^{\text {th }} 815$ at 836-37; 982 P. 2d 229 at 242 (1999)

${ }^{36}$ Lucille M. Ponte, "Putting Mandatory Summary Jury Trial Back On the Docket:

Recommendations on the Exercise of Judicial Authority" 63 Fordham L. Rev. 1069 at p.1069 (1995) 
been disproportionately fueled by business cases. Further, some commentators (and even some prominent judges) point out that the claim of a "litigation explosion" is vastly exaggerated, ${ }^{37}$ if not outright false. ${ }^{38}$ Finally, many business executives and their corporate counsel are discovering that private A.D.R. does not always live up to its billing in this regard, and if anything, often results in excessive delay. ${ }^{39}$

\section{(b) Expense}

Private A.D.R. is often touted as being cheaper than traditional litigation. ${ }^{40}$ There is also evidence that suggests that business executives and their in-house counsel at least perceive that the traditional court system is too expensive. ${ }^{41}$ However, due to a lack of empirical data, it is unclear whether A.D.R. is, in fact, cheaper than traditional litigation. ${ }^{42}$ Some commentators contend that it is not, ${ }^{43}$

${ }^{37}$ Some exaggeration is no doubt the result of the fallout of the long-standing political duel between the plaintiffs' bar and the insurance defense industry: the trial attorneys in many states have been able to block insurance-funded tort reform efforts but the insurance industry has countered by raising the spectre of third party claims, frivolous lawsuits, and litigation gridlock which has resulted in procedural changes which favour their interests. See, e.g., in the British context, Robert C. Meder \& Stephen J. Vickers, "The Woolf Reforms" Risk Management, (Sept. 1999) at pp.32-40.

${ }^{38}$ See, e.g., Marc Galanter, "Real World Torts: An Antidote to Anecdote" 55 Md. L. Rev 1093 at pp. 1102-09 (1996); Jack B. Weinstein, "After Fifty Years of the Federal Rules of Civil Procedure: Are the Barriers to Justice Being Raised?" 137 U. Pa. L. Rev. 1902 at p. 1909 (1989).

39 See, e.g., Harold Brown, "Alternative Dispute Resolution Realities and Remedies" 30 Suffolk U. L. Rev. 743 at pp. 767-768 (1997); Jeffrey G. Kichaven, "ADR Does Not Save Time or Money? Great News!" Disp. Resol. Mag., (Summer 1997) at p. 15.

${ }^{40}$ E.g., The C.P.R. Institute for Dispute Resolution claims that for a five-year period ending in 1995,652 companies using C.P.R panelists reported a total cost savings of over $\$ 200$ million, with an average cost savings of more than $\$ 300,000$ per company. See $<$ http://www.cpradr.org/poll 597.htm>.

41 See John Lande, "Failing Faith in Litigation? A Survey of Business Lawyers and Executives Opinions" 3 Harv. Neg. L. Rev. 1 at pp.35-36 (1998).

${ }^{42}$ See, e.g., Richard E. Reuben, "The Dark Side of ADR" Cal. Low., (February, 1994) at p. 54 ("For all the promised benefits of ADR, independent statistics documenting them are almost nonexistent. One reason is the secrecy of the proceedings; few records exist for researchers to examine."), Editorial, "Mandatory ADR: Can We Talk?" 78 Judicature (MayJune, 1995) at p. 272 (noting the lack of empirical support for many A.D.R. claims).

${ }^{43}$ See $e . g$., Reuben, ibid (citing an arbitration that produced a $\$ 15,000$ award and $\$ 6,000$ in attorneys fees but was more than offset by a $\$ 30,000$ legal bill and $\$ 9,000$ for the arbitrator's services, and how, had the case stayed in the public system and gone to trial, the parties would not have had to even pay for the judge); James J. Alfini, "Summary Jury Trials in State and Federal Courts: A Comparative Analysis of the Perceptions of Participating Lawyers" 4 Ohio St. J. on Disp. Resol. 213 at pp.229-231 (1989) (study in which a majority of the federal 


\section{THE DENNING LAW JOURNAL}

and as Marc Galanter notes, critics of the cost aspect of litigation often ignore the benefits:

"[S]ociety's accounts should reflect not only the costs but the benefits of enforcing such transfers, which afford vindication, induce investments in safety, and deter undesirable behavior. For instance, the sums transferred by successful patent infringement litigation not only are not lost, but maintain the credibility of the patent system that in turn has powerful incentive effects. To put forward estimates of gross costs - even ones that are not makebelieve - as a sufficient grade to policy displays indifference to the vital functions that the law performs.

\section{(c) Perceived Juror Ignorance and Bias Against Business}

Another reason why businesses in the United States may be increasingly turning to private A.D.R. is because they believe that juries do a poor job determining liability and assessing damages in lawsuits against businesses and they judge businesses more harshly than individuals. ${ }^{45}$ The following statement from a business executive is typical:

"Is it any surprise that many commercial contracts these days have a clause where each party waives its right to a trial by jury? Doesn't that tell you something? That they are not willing to trust 12 peers off the street with the complexity of their business transaction .... and that doesn't mean that people are stupid. It means that businesses have become very complex in many respects. The nature of their product offerings, not necessarily how the business is run, but the nature of the products. Open up the insides of a laptop computer and try to have some jury decide whether or not there has been a patent infringement on the design of a microchip. I certainly wouldn't be capable of doing that. $^{46}$

\footnotetext{
summary jury trial was used).

44 ,Galanter, supra n.38 at p. 1142.

45 See Lande, supra n. 41 at pp.33-34

46 Ibid at p.34.
}

lawyers asserted that their billable hours increased when the A.D.R. mechanism of a 


\section{UNCOMMON LAW}

Yet, the research of several prominent scholars strongly suggests that if anything, the contrary is true and that juries do know what they are doing and do give businesses the benefit of the doubt. ${ }^{47}$

(d) Perceived Lack of Expertise in the Judges Presiding Over Business Disputes Another oft-touted benefit of many forms of private A.D.R. is the ability to select a "dispute resolver" with "expertise" in the business issue at hand. Judges in the traditional court system, on the other hand, are sometimes perceived to lack such expertise, ${ }^{48}$ especially by business executives. ${ }^{49}$ To the extent that a lack of such expertise exists, the politicization of judicial selections ${ }^{50}$ and even their salaries ${ }^{51}$ may contribute to the problem. Yet the lack of expertise is by no means unique to judges in the traditional court system. If anything, businesses are finding that it may be even more acute with respect to many purported "A.D.R. specialists."

(e) Privacy and Confidentiality

With private A.D.R., the parties can obtain a large measure of privacy and confidentiality. Often being a private proceeding, A.D.R. allows businesses to resolve their disputes without creating a public record. ${ }^{53}$ For a business

${ }^{47}$ Valerie P. Hans \& William F. Lofquist, “Jurors' Judgments of Business Liability in Tort Cases: Implications for the Litigation Explosion Debate" 26 L. \& Soc'y Rev. 85 (1992); Valerie P. Hans, "The Contested Role of the Civil Jury in Business Litigation" 79 Judicature 242 (1996); Galanter, supra n.38 at p. 1109

${ }^{48}$ Peter Zeughauser notes:

"[W]hat sober minded business person wants an important dispute decided by ... a former D.A. who was appointed to the bench because of his or her skill in locking people away for crimes that were more often than not selfevident?"

Peter D. Zeughauser, "What's in a Name? Plenty" Am. Law., (April, 1996) at pp.44.

${ }^{49}$ Lande, supra n. 41 at pp. 32, 34-35.

${ }^{50}$ For an interesting historical discussion on the selection of federal judges in the United States and the politicization of the process, see Sheldon Goldman, Picking Federal Judges: Lower Court Selection From Roosevelt Through Reagan (Yale Univ. Press, 1997). For the same regarding President Bush's and President Clinton's appointees, see Sheldon Goldman, "Bush's Judicial Legacy: The Final Imprint" 76 Judicature 287 (1993) and Sheldon Goldman \& Elliot Slotnick, "Clinton's Second Term Judiciary: Picking Judges Under Fire" 82 Judicature 265 (May-June, 1999).

s1 See William C. Smith, "Bailing From the Bench" A.B.A. J., (May, 1999) at p.22 (discussing how the disparity between law firm salaries and judicial salaries is driving experienced judges from the bench).

52 See Harold Brown, supra n. 39 at pp. 758 \& 760

${ }_{53}$ See generally, William H. Schroder, Jr., "Private ADR May Offer Increased Confidentiality" Nat'l L. J., (25 July, 1994) at C14-16. 


\section{THE DENNING LAW JOURNAL}

concerned about eroding public confidence in its product or services, any proceeding that allows it to resolve its disputes out of the public eye is attractive. ${ }^{54}$ Similarly, A.D.R. is often attractive to a businesses concerned about being forced to reveal one or more of its trade secrets during litigation. ${ }^{55}$ Businesses may also seek to avoid creating a legal precedent that may later prove to be disadvantageous to them or their industry, and are thereby drawn to any A.D.R. process in which the likelihood of a successful appeal is small. ${ }^{56}$

However, many businesses are discovering that the touted privacy and confidentiality of private A.D.R. is by no means a sure thing and can be problematic. For example, with respect to mediation, judges that have ordered a case to mediation often request a status report from the mediator in order to determine who is bargaining in good faith and who is foot-dragging. ${ }^{57}$ In other cases, criminal prosecutors may call the third party neutral to testify. ${ }^{58}$ There are also situations in which a company's decision to seek refuge in the privacy of A.D.R. backfires. Consider a large corporation who has been sued by multiple customers. Assume that the company believes that all of the cases are without merit, but agrees to mediation, and for economic, publicity, or risk considerations agrees to pay ten cents on the dollar to settle the first ten cases. When mediating the eleventh case, the company may, as part of its strategy, wish to use this data to its advantage and as evidence of what the case is "worth." Yet, and depending upon the confidential settlement terms that were reached and agreed to during the first ten mediations, the company and its counsel may have failed to think things through and inadvertently waived the ability to utilise such information in the eleventh case. ${ }^{59}$

\section{(f) The Advertised Ability of A.D.R. to Provide "Win-Win" Business Solutions} and Preserve Business Relationships

Yet another touted advantage of private A.D.R. is its ability to offer "win-win" solutions in a business dispute that courts cannot provide. A.D.R. is often

\footnotetext{
54 See Judith Resnik, "Failing Faith: Adjudicatory Procedure in Decline" 53 U. Chi. L. Rev. 494 at p.538 (1986).

55 See Tom Arnold, "A Better Mousetrap: ADR" Vol. XXX No. 1, Les Nouvelles,(March 1995) at p.34

56 See Brown, supra n.39 at p.764 (discussing the common standards for reviewing and challenging an arbitrator's legal and factual findings in the United States - "manifest disregard of the law," "arbitrary and capricious," and "completely irrational" - and how these standards are very difficult to satisfy.).

57 See Michael Higgins, "In the Spirit of Mediation" A.B.A. J., (March. 1998) at pp.94-95.

58 Ibid.

59 One of the authors was involved in a recent mediation that posed a similar issue for the opposing party and its corporate counsel.
} 


\section{UNCOMMON LAW}

viewed as being less hostile than traditional litigation, thereby allowing businesses to better preserve ongoing relationships. ${ }^{60}$ Yet these claimed benefits are often overly simplistic, presumptuous, and even misleading. There is nothing that prevents an attorney in traditional litigation from exploring and implementing "win-win" solutions. In fact, a well-trained attorney does so and skillfully uses the tools and leverage of the court system to attain that goal as quickly as possible for his or her client. ${ }^{61}$ Moreover, some commentators persuasively argue that many disputes involve such important issues that they should be litigated, and that the "feel-good" results of A.D.R. are often inferior to those obtained in traditional litigation. ${ }^{62}$

\section{V.Changes in How Courts Service Business Disputes}

While there is disagreement in the United States about whether a "litigation explosion" has occurred, there is little doubt that many people perceive that one has occurred. How has the American judiciary attempted to cope with this perceived increase in its workload? Primarily through the following tools: managerial judging; a process labeled "self-bureaucratization:" forcing business cases into some form of A.D.R. (often against their will); and finally, the increased use of vacatur, selective publication, depublication, filings under seal and confidential settlements. Thus, and as shown below, for the business cases that do opt to enter into the traditional court system and avoid private A.D.R., these tools amount to yet another level and form of privatization, thereby further distorting and thwarting the growth of our body of commercial law.

\section{(a) Managerial Judging}

Judith Resnik has written about what she calls "managerial judging" - where judges become involved in the pretrial management of the case to try and relieve perceived court congestion (e.g., ruling on discovery disputes, deciding joinder issues, conducting pretrial conferences, settlement conferences, and the

\footnotetext{
60 Arnold, supra n.55 at pp.33-34

61 The following is a common example in traditional American litigation: One party sends out a series of document requests, deposition notices and interrogatories with a settlement offer. The settlement offer is timed to expire shortly before the discovery is due. This strategy can and often does serve as an effective impetus to get the parties to sit down, communicate, and resolve the case.

62 See, e.g., Owen Fiss, "Against Settlement" 93 Yale L. J. 1073 (1984); Marc Galanter \& Mia Cahill, "Most Cases Settle': Judicial Promotion and Regulation of Settlements" 46 Stan. L. Rev. 1339 (1994).
} 
like). ${ }^{63}$ This type of judging poses several dangers. First, a deeper involvement by judges in the pretrial phase of the case may compromise their independence and prematurely cause them to favor one side or position in the dispute, which will in tum impact the quality of their deliberations. Second, and even more importantly for the purposes of this article, managerial judging undercuts the obligation and requirement that judges act in public and formally record and document the reasons behind what they do (or do not do).

The following is an example: in the past a young attorney in the United States who wanted to learn how a particular judge handled pretrial matters (e.g., discovery motions) used to be able to walk over to the courthouse and spend the morning sitting in the gallery of the judge's courtroom and observe the judge rule on various law and motion matters. But this is becoming more and more difficult to accomplish. Today, it is not uncommon for the case to be called, the parties' counsel led into the judge's private chambers (or more likely a conference room), sit down and discuss the case with the judge (or more likely a discovery referee or judge pro tem), no court reporter is present, and the matter is argued and decided. This same routine is then repeated for every case on the calendar. Relatedly, and perhaps even more disturbingly, today's courts and judges in America are often evaluated not for the quality of their decisions (e.g., how often they are appealed and reversed), but for their ability to move cases along and clear the docket. ${ }^{64}$ While the impact of this management philosophy on the development of our contemporary body of commercial law is difficult to measure, we submit that it is more deleterious than beneficial.

\section{(b) Judicial Bureaucratization}

The United States has also witnessed an increase in the size of the judiciary, its support staff (e.g., magistrates, special masters, judge pro tems, discovery referees, law clerks, staff attorneys, and the like), as well as judges' reliance on those staff. ${ }^{65}$ Some refer to this development as the "bureaucratization of the judiciary. "66 When judges delegate responsibility for initially assessing or deciding portions of a case to someone else in the courthouse, they diminish

\footnotetext{
63 See Judith Resnik, "Managerial Judges" 96 Harv. L. Rev. 376 (1982); Resnik, "Failing Faith" supra n.54

64 E.g., the California Judicial Council publishes time-on-the-docket statistics for some of its courts. See Judicial Council of California, Report on Court Statistics (1997) at p. 17. These statistics inevitably become ammunition in various political and public policy battles

${ }^{65}$ See Owen M. Fiss, "The Bureaucratization of the Judiciary" 92 Yale L. J. 1442 at pp.14421468 (1983); Joseph Vining, The Authoritarian and the Authoritative (University of Chicago Press, 1986), at pp.51-57; and Alvin B. Rubin, "Bureaucratization of the Federal Courts: The Tension Between Justice and Efficiency" 55 Notre Dame L. Rev. 648 at p.650 (1980).

${ }^{66}$ Fiss, ibid; Vining, ibid; \& Rubin, ibid at pp.648-659
} 
their own level of personal responsibility for their decisions, which in turn leads to greater anonymity in judging. This results in the impression that these decisions have not been rendered or written by an individual with an identity of their own, but are instead the product of an impersonal institution. The downside of such impersonalization is that it gives businesses yet another reason to flee the court system for private A.D.R., thereby further distorting the growth of our commercial precedent.

\section{(c) Courts Forcing Business Cases Into A.D.R. Against Their Will}

It is not just a case of businesses seeking to avoid the traditional court system.

Even our own courts have made the conscious policy decision to divert business cases into A.D.R. in order to conserve judicial resources. ${ }^{67}$ Thus, for the business that does opt into the court system and have its "day in court," it is likely to find itself entangled in the very form of dispute resolution - A.D.R. -that it sought to avoid from the beginning. ${ }^{68}$ It is therefore ironic that even though business tax dollars help pay for the American court system, courts have sent the message that such judicial welfare is reserved for other types of cases; namely, criminal cases, family law cases, civil rights cases, and the like. Again, while the impact of this diversion process on our contemporary body of commercial law is difficult to measure, we submit that it is more harmful than beneficial.

${ }^{67}$ While court use and promotion of A.D.R. was not unheard of prior to the 1970 s, the 1976 Pound Conference on the Causes of Popular Dissatisfaction with the Courts (co-sponsored by Chief Justice Warren Burger, the Judicial Conference of the United States, and the American Bar Association) was the first major push in the United States to consider alternative ways to inexpensively and more efficiently obtain justice in the courts. Since the Pound Conference, the use of A.D.R. by courts took off and has only accelerated. See, e.g., Patrick Fn'Piere \& Linda Work, "On the Growth and Development of Dispute Resolution" 81 Ky. L. J. 959 at pp.962-963 (1993)

${ }^{68}$ See Stephen P. Younger, "Effective Representation of Corporate Clients in Mediation" 59 Alb. L. Rev. 951 at pp.951-52 (1995) ("With increasing frequency, our courts are encouraging litigants to use [A.D.R.] procedures ... to clear up overburdened court calendars."); Jacqueline M. Nolan-Haley, "Court Mediation and the Search for Justice Through Law" 74 Wash. U. L. Q. 47 at pp $48-49$ (1996) ("Within the last fifteen years, in both state and federal courts, litigants have often been required to attend [an A.D.R.] session before they will be allowed to be heard by a judge."); Ibid at p.52 ("As [A.D.R.] programs are institutionalized ... litigants find themselves directed off their original course of seeking justice through law."). 
(d) Vacatur, Selective Publication and No-Citation Rules, Depublication, Filings Under Seal and Confidential Settlements

Yet another tool that the courts in the United States have implemented to address the perceived workload problem has been to make (or allow) the increased use of vacatur, selective publication and the adoption of no-citation rules, depublication, filings under seal and confidential settlements. As shown below, each of these tools is a form of privatization that further subtracts from our body of commercial law.

\section{Vacatur}

One development that has recently been the subject of robust debate is the increasing use of vacatur, where, after a trial court reaches a decision and issues a judgment, the parties reach a private settlement rather than pursue further appeals. As a condition of their settlement, the parties request the appellate court to vacate the lower court's prior judgment. ${ }^{69}$ Vacatur, however, not only erodes the public's confidence in the courts, ${ }^{70}$ but it prevents the use of judgments for collateral estoppel purposes, diminishes the stare decisis value of judgments, and most importantly, alters the shape and development of our business and commercial precedent. ${ }^{71}$

\section{Selective Publication and No-Citation Rules}

The decision by many court systems to selectively publish certain decisions is yet another form of privatization. ${ }^{72}$ This decision by appellate courts was largely

${ }^{69}$ A detailed discussion and analysis of vacatur is beyond the scope of this article. But for a good discussion on vacatur, its history, usage rate, advantages and disadvantages, scope, and the debate surrounding its use, see Howard Slavitt, "Selling the Integrity of the System of Precedent: Selective Publication, Depublication, and Vacatur" 30 Harv. C.L. -- C.L. L. Rev. 109 (1995), Judith Resnik, "Whose Judgment? Vacating Judgments, Preferences for

Settlement, and the Role of Adjudication at the Close of the Twentieth Century" 41 U.C.L.A. L. Rev. 1471 (1994); and Stephen R. Barnett, "Making Decisions Disappear: Depublication and Stipulated Reversal in the California Supreme Court" 26 Loy. L.A. L. Rev. 1033 (1993). ${ }^{70}$ In Neary v. Regents of the University Of California, Justice Joyce Kennard of the California Supreme Court wrote that "Public respect for the courts is eroded when this court decides that a party who has litigated and lost in the trial court can, by paying a sum of money sufficient to secure settlement conditioned on reversal, purchase the nullification of the adverse judgement." Neary, 3 Cal. $4^{\text {th }} 273$ at $287 ; 834$ P.2d 119 at $127 ; 10$ Cal. Rptr. $2 d$ 859 at p. 867.

${ }_{71}$ Slavitt, supra $\mathrm{n} .69$ at pp. 133-134.

72 Again, a detailed discussion and analysis of selective publication is beyond the scope of this article. But for a good discussion of selective publication, its history, usage rate, advantages and disadvantages, scope, and the debate surrounding its use, see Slavitt, supra n.69; Gerald F. Uelmen, "Publication and Depublication of California Court of Appeal 
motivated by work flow and shelf-space concerns regarding the burgeoning quantity of case decisions. ${ }^{73}$ But as with vacatur, selective publication has resulted in a significant loss of available contemporary cases to use as a guide in resolving similar disputes. ${ }^{74}$ One commentator notes:
"Selective publication suppresses precedent that would help courts decide future cases. In addition, even if selective publication saves time, it distorts the shape of precedent.
Lawyers use precedent to evaluate how courts apply the law across a broad range of cases as much to identify what a precise rule of law is. One cost of saving time, then, is that it leaves the law unclear and may ultimately lead to more litigation to clarify the law. The long-term costs of distortion, therefore, may outweigh any short-term efficiency of savings ... By making the law more certain, it also allows individuals to structure their affairs to avoid disputes and litigation..75

An additional concern that has been raised with respect to selective publication is that a court, knowing that it is not going to certify a case to be published, may not devote the same amount of energy to its decision. ${ }^{76}$ The

Opinions: Is the Eraser Mightier than the Pencil?" 26 Loy. L.A. L. Rev. 1007 (1993); William L. Reynolds \& William M. Richmond, "The Non-Precedential Precedent - Limited Publication and No-Citation Rules in the United States Court of Appeals" 78 Colum. L. Rev., 1167 (1978). See also the web site Nonpublication.com at info@www.Nonpublication.com.

${ }^{73}$ See generally, Slavitt, supra n.69 at p.123; and Charles E. Carpenter, Jr., "The No-Citation Rule for Unpublished Opinions: Do the Ends of Expediency for Overloaded Appellate Courts Justify the Means of Secrecy?" 50 S.C. L. Rev. 235 at pp.243 \& 249 (1998).

${ }^{74}$ See Hinderks \& Leben, supra $n$. 16 at p. 158 (noting that over 60 percent of federal circuit court decisions are not published); and Gerald F. Uelmen, "Losing Steam" Cal. Low., (June, 1990) at p.43; and Philip L. Dubois, "The Negative Side of Judicial Decision Making: Depublication as a Tool of Judicial Power and Administration on State Courts of a Last Resort" 33 Vill. L. Rev. 469 at p.488 (1988) (collectively pointing out that less than fifteen percent of appellate decisions in California are even certified for publication and of that fifteen percent, the California Supreme Court orders an additional ten percent depublished) Since these articles were published the number of California Courts of Appeal decisions marked by California appellate judges who author them as "not to be published in the Official Reports" under Rule 976 of California Code of Civil Procedure has risen to 93 per cent ! See California Bar Journal (July, 2000) at p.9.

${ }^{75}$ Slavitt, supra n. 69 at pp. $126 \& 140$

${ }^{76}$ See Carpenter, supra $n .73$ at $p .251$ (noting that "[I]f judges know that their opinions are not citable and that they will not have to sign the opinions, the same 'quality control' pressures will not be in place."). For a cogent critique and criticism of this short cut by judges, see Anthony Kronman The Lost Lawyer (Harvard 
selective publication problem is further aggravated by its usual companion, the no-citation rule. ${ }^{77}$ However, if unpublished opinions are to be treated in a manner consistent with the common law model, then they should be citable and used as binding authority. ${ }^{78}$

\section{Depublication}

Many higher appellate courts are now depublishing certain decisions because they disagree with a lower court of appeal over a portion of its reasoning. ${ }^{79}$ As with vacatur and selective publication, depublication is form of privatization that has resulted in a loss of available contemporary cases to use as a guide in resolving similar disputes. For example, in California, the California Supreme Court depublishes more appellate opinions each year than it publishes opinions of its own. ${ }^{80}$ Further, only seven percént of all appellate decisions in California are even certified for publication.

\section{Filings Under Seal and Confidential Settlements}

In the United States most pretrial activity is not accessible to the public. ${ }^{82}$ This is certainly true with respect to most pretrial discovery. ${ }^{83}$ Yet, in spite of this

University Press, 1995) at pp.330-331. Dean Kronman argues that opinion writing disciplines the imagination and if a judge determines that an opinion "won't write," then that means his or her logic or reasoning is flawed and that he or she needs to go back and rethink the matter.

${ }^{77}$ Carpenter, supra n. 73 at p.236. No-citation rules are just what the name implies -- they prohibit the citation to unpublished opinions.

${ }_{78}$ Carpenter, ibid at p.240

79 As with vacatur and selective publication, a detailed discussion and analysis of depublication is beyond the scope of this article. But for a good discussion of depublication, its history, usage rate, advantages and disadvantages, scope, and the debate surrounding its use, see Slavitt, supra n.69; Uelmen, supra n. 72; Barnett, supra n.69; Dubois, supra n. 74; and Joseph R. Grodin, "The Depublication Practice of the California Supreme Court" 72 Cal. L. Rev. 514 (1984).

${ }^{80}$ Uelmen, supra n. 74 at pp. $34 \& 43-44$

81 See Uelmen and Dubois, supra n.74. Related to the vacatur, selective publication and nocitation rules, and depublication problem is the increased issuance of appellate decisions "without comment" and the decreased use of oral argument in appellate cases, both of which distort precedent. See, e.g., William C. Smith, "Big Objections to Brief Decisions" A.B.A.J., (August, 1999) at p.36 (noting that last year the federal appeals courts disposed of 25,020 appeals on the merits, about six percent of which were disposed of "without comment," meaning the court did not expound the law as applied in the case or did not explain the reasons for the ruling); and Carpenter, supra n.73 at p.255 n. 55 (noting the "increasingly frequent cases where the court hears no oral argument and issues an unpublished opinion based solely on the briefs").

${ }^{82}$ See Resnik, supra n.69 at p.493 n.84. 
fact, there is a "growing tendency" throughout the courts, "especially in commercial cases, for litigants to agree to seal documents produced during the discovery process as well as pleadings and exhibits filed with the court" and to keep settlements confidential. ${ }^{84}$ This tactic, however, not only eliminates precedent, but also precludes third parties from obtaining such information ${ }^{85}$ and imposes substantial costs on future litigants who may not know of the underlying wrong. ${ }^{86} \mathrm{Or}$, even if these other litigants are aware of the wrong, they must proceed to conduct expensive discovery to prove once again that a wrong occurred. ${ }^{87}$

\section{Vi. Corporate Megafirms Further the Privatization Process and UNDERCUT THE GROWTH OF THE COMMON LAW}

We have highlighted how in order for commercial precedent to develop and grow, business cases must enter (and remain in) the court system, they must be tried and their records kept public, verdicts must be rendered, appeals pursued, and appellate opinions published. Popular perception would have us believe that today's lawyers in the United States are trying cases and putting that process in motion. However, this perception is not the reality for the vast majority of today's litigators. Most cases are resolved by negotiated settlements. ${ }^{88}$ Traditional litigation in the form of a trial and appeal is the exception. ${ }^{89}$ Kevin McMunigal states it perfectly:

"The last two decades have seen a population explosion in the legal profession, and much of the new manpower is employed exclusively in work related to lawsuits. These lawyers are usually not trial lawyers. They are called "litigators." Few of

\footnotetext{
83 See Resnik, ibid at p.1493 n.85.

${ }^{84}$ Nault's Auto. Sales, Inc. v. American Honda Motor Co., 148 F.R.D. $25 ; 43$ (D.N.H. 1993)

85 See, e.g., Ralph Nader \& Wesley J. Smith, No Contest (Random House, Inc. 1996). Nader and Smith remind us that "information is power" and that "in order for people to make informed decisions about how they will conduct their lives, about which products to purchase and which to avoid, about which companies to patronize, and the like, they need access to information." at p.61.

86 Ibid at pp.60-75.

${ }^{87}$ Ibid.

88 See Kevin C. McMunigal, "The Costs of Settlement: The Impact of Scarcity of Adjudication on Litigating Lawyers" 37 U.C.L.A. L. Rev. 833 at pp.838-839 nn. 15 \& 17-19 (1990) (and the authorities cited therein).

89 Ibid. See also, Kleiner, supra n.32 at p.90 ("Just a fraction of legal matters are ultimately resolved in court.").
} 


\section{THE DENNING LAW JOURNAL}

them have had jury experience, and if they participate in a bench trial it would be as a "second chair" to a trial lawyer. It is important to understand that the litigator is not simply a young lawyer acquiring experience that will equip him to start trying cases. Litigators are now a separate specialty. There are many 50-year old litigators whose trial experience has been negligible. They are highly regarded in their specialty and conduct seminars attended by those who wish to improve their own skills as litigators. And they are in charge of training the new generation of litigators." 90

He goes on to add:

"[Unlike the discovery lawyer] [t]he experienced trial lawyer understands the ultimate end of the discovery process. He knows that everything he does is directed to the single goal of convincing the judge or jury. When the experienced trial lawyer prepares a case, he never loses sight of the fact that he is structuring the case for trial. In a sense, he is constantly asking what do I need for trial? How can I get it quickly? ...

All too often the discovery lawyer with little trial experience is uncertain and lacks direction. This is particularly so in large cases where the lawyer who prepared the case not only will not try it but may only be familiar with one small aspect of the case. In such a case the discovery tends to lack direction because the lawyer does not know where he is going or why he's doing certain things. More depositions are taken than needed.

Witnesses are deposed who are not needed and who should not have been deposed at all. Objections and evasions are frequent because the discovery lawyer just isn't sure how the senior man will try the case and doesn't want to be criticized for not protecting the client.

The lawyer's lack of trial experience causes him anxiety and uncertainty. Because he is not confident all too often the tendency is to try to insure that absolutely nothing is left uncovered. The discovery goes on interminably as every conceivable stone is turned. The unfortunate result is misused

${ }^{90}$ McMunigal, supra n. 88 at p.840. 


\section{UNCOMMON LAW}

discovery, overdiscovery, expensive discovery, and at times, harmful discovery." 91

What is the reason for the advent of the "discovery lawyer?" Some proffered reasons include the procedural opportunities created by the Federal Rules of Civil Procedure; the staffing needs of large-scale litigation; the simultaneous decline in trial rates with an increase in the number of lawyers, and so on. We suggest an alternative reason: large corporate law firms, their current structure and organization, and their corresponding failure to properly train and mentor their junior attorneys for trial work. ${ }^{92}$

By way of background, in 1991, forty-seven percent of all lawyers in private practice in the United States were in firms of twenty-one or more lawyers, including thirty-three percent in firms of fifty-one or more lawyers. ${ }^{93}$ Today this figure is undoubtedly higher. ${ }^{94}$ This is not to say that the influence of smaller law firms and solo practitioners on our body of commercial law is insignificant. But the reality is, large corporate law firms handle the majority of legal work for most (if not all) major U.S. companies, and they exercise power and influence well beyond their numerical strength. ${ }^{95}$

In the past, the mentoring and training of junior lawyers to become skilled trial attorneys was an important part of the institutional structure of these firms. ${ }^{96}$ But today, that is no longer the case. Despite their claims to the contrary, they have become driven by the "bottom line." The effective mentoring and training of their junior attorneys is no longer a priority. ${ }^{98}$

91 Ibid at p.870.

92 For an excellent discussion on the arrival, growth and transformation of the large corporate law firm in America, see Marc Galanter \& Thomas Palay, Tournament of Lawyers: The Transformation of the Big Law Firm (University of Chicago Press, 1991); and Kronman, supra n.76 at pp. 271-314.

${ }^{93}$ Barbara A. Curran \& Clara N. Carson, The Lawyer Statistical Report: The U.S. Legal Profession in the 1990s (American Bar Foundation, 1994), at p.8.

94 Lewis A. Kornhauser \& Richard L. Revesz, "Legal Education and Entry Into the Legal Profession: The Role of Race, Gender, and Educational Debt" 70 N.Y.U. L. Rev. 829 at p.839 (1995) (noting that in the practice of law "there [has been] a marked shift to practice in larger settings").

95 For an excellent elaboration of this point, see Kronman, supra n.76 at pp.272-273.

96 For an excellent example, see Patrick J. Schiltz, "Legal Ethics in Decline: The Elite Law Firm, the Elite Law School, and the Moral Formation of the Novice Attorney" 82 Minn. L. Rev. 705 at pp. $720-722$ (1998)

97 See John J. Curtin, Jr., "Civil Matters" A.B.A. J., (August, 1991) at p. 8 ("The law is edging ever closer to being a business rather than a profession, a development which emphasizes the bottom line above all other concerns."); Galanter \& Palay, supra n.92 at pp.2-3 ("[Although] laments about commercialization and the loss of professional virtue have recurred regularly 
This development has manifested itself in a variety of ways, each of which has contributed to (and continues to contribute to) the advent of a generation of discovery lawyers who do not know how to try a business case. For example, the compensation of partners in these firms (and decisions about who makes partner) focus almost exclusively on the business and revenue that the partner generates. ${ }^{99}$ The partner who brings in business and is able to keep as many associates as possible busy in his or her practice group can expect to be handsomely rewarded by the firm. The partner who takes a daily hands-on approach to the legal work of a business client and uses that process to train and mentor the firm's junior lawyers is unlikely to fare as well. ${ }^{100}$ The impact of this management philosophy and institutional structure on mentoring and training is obvious. Second, the associates in these firms are under tremendous pressure to bill hours ${ }^{101}$ and at the same time bring in new business. ${ }^{102}$ They are also expected to hit the ground running to justify their high starting salaries. ${ }^{103}$ There is, quite simply, no time for junior attorneys to be mentored and trained in a personal, deliberative and thoughtful way. Third, the increased lateral movement of attorneys has caused many corporate law firms to view junior attorneys as "dispensable worker bees" rather than someone they should invest in and train to become quality trial lawyers. ${ }^{104}$ Finally, in an intensely competitive legal environment, many corporate law firms will not hesitate to try

for a century ... there is something different this time around. The present 'crisis' is the real thing ...." (footnote omitted).

98 Schiltz, supra n.96 at pp.739-746. In the March, 1989 issue of the California Lawyer, it was reported that many California firms are using outside consultants for training in trial skills. See Paul D. Freeman, "Teach the Associates Well" Cal. Law., (March. 1989) at p.77. However, McMunigal suggests that while the articulated reason for using such consultants is "efficiency," an alternative explanation may be that even the partners in today's law firms lack the necessary trial skills to provide such training. McMunigal, supra n.88 at p.852 n.82. 99 See, e.g., Galanter \& Palay, supra n.92 at pp.52-53

100 In working for and litigating against large corporate law firms, the authors have seen many such examples. Interestingly, there are even cold, calculating mathematical formulae that such firms use to measure profitability and performance. See, e.g., Altman Weil, Inc.'s (a global consulting firm to the legal profession) web page at:

$<\mathrm{http}$ //www.altmanweil.com/publications/articles/economic_financial_management/efm3a.h $\mathrm{tm}>$

$\overline{101}$ Schlitz, supra n.96 at pp.739-740. See also, Terry Carter, "Superstars or Falling Stars?" A.B.A. J., (August, 1998) at p.28 (putting the current billable hour "gold standard" at corporate law firms at 2,400 hours per year). As McMunigal notes, such an institutional structure "may create pressures for lawyers to file meritless cases to generate hourly fee work in discovery and motion practice." McMunigal, supra n.86 at p.864.

102 Schlitz, supra n.96 at p. 741 .

103

104

Ibid at p.743

Ibid at p. 744 . 


\section{UNCOMMON LAW}

and lure clients away from competing firms ${ }^{105}$-- time that a lawyer spends courting a competitor's client decreases the number of hours in a day available for providing or receiving mentoring and training.

Unfortunately, this focus and institutional structure distorts our system of commercial precedent. Among other things, the discovery lawyers that these firms grow and produce undoubtedly increase litigation expense which in turn likely causes some businesses to flee the public court system and turn to private A.D.R. to resolve their disputes. Further, because many discovery lawyers lack confidence in their trial skills, they may consciously (or subconsciously) seek out private A.D.R. in order to minimize their own stress or embarrassment. ${ }^{106}$ For the few discovery lawyers that do actually end up trying a business case, it is not uncommon to see a polluted trial court record subsequently presented to the court of appeal, ${ }^{107}$ thereby perhaps. leaving an appellate court with no choice but to use the privatization tools of selective publication and depublication.

\section{Additional Dangers Posed by the Privatization Process}

Any mechanism that privatizes the resolution of business disputes distorts our system of precedent and will have a significant impact on the business community. But we submit that the American business community, those governing and advising it, and even the judiciary has not honestly, intelligently, and fairly evaluated and weighed the benefits of this privatization process against the harms. In addition to stunting the growth of commercial precedent, the following are some additional dangers to consider.

\section{(a) The Loss of Information and Reduction of the Public Intent}

As earlier noted, one of the attractive features of private A.D.R. is that certain things can remain private and confidential. However, this results in a significant amount of information that is difficult to track and lost to the public. Further, to the extent that public disclosures are made during the privatization process,

\footnotetext{
los Ibid at p.741.
}

106 McMunigal, supra n.88 at p.873 (1990). Relatedly, McMunigal makes the point out that when the number of civil trials declines, litigators' advocacy skills atrophy. This degeneration process in turn distorts not only the trial skills of litigators, but also the settlement process. In other words, litigators without adequate trial experience are less able to accurately evaluate cases and are more likely to settle out of fear of their own inadequacy. Ibid at pp 855-862.

107 See Burger, "Some Further Reflections on the Adequacy of Trial Counsel" 49 Fordham L. Rev. 1 at p.1 (1980) ("a broad consensus has now emerged that a significant problem concerning the quality of a substantial number of lawyers' performance in the trial courts does indeed exist."); Rubin, supra n.65 at p.649 ("Today appeals involve records of thousands of pages and briefs and arguing dozens of issues.") 


\section{THE DENNING LAW JOURNAL}

they are often not tracked, memorialized and stored. ${ }^{108}$ There is already a scarcity of data and information available to scholars who study private A.D.R. and the court system. ${ }^{109}$ The privatization of business disputes only adds an additional layer of fog that makes the meaningful study and analysis of such issues all the more difficult.

Further, if we are serious and sincere about protecting the public intent, much of the information that is normally hidden by private A.D.R. should be made available to the public. Consider, for example, the American company, Whirlpool Corporation. Several years ago Whirlpool entered into an agreement with State Farm Fire and Casualty Company that "established a process for resolving State Farm's subrogation claims against Whirlpool arising out of products sold by Whirlpool which allegedly caused property damage to State Farm's insureds." from the public court system and resolve their disputes pursuant to mediation and arbitration. ${ }^{111}$ The companies streamlined discovery rules and eliminated outside lawyers from the process. ${ }^{12}$ The proceedings and all decisions are kept confidential, and thereby inaccessible to the plaintiff's bar. ${ }^{113}$

This arrangement is undoubtedly of great value and benefit to Whirlpool and State Farm. Yet there are compelling reasons why such agreements violate public policy and such information should be revealed. In a typical products liability lawsuit, for example, the negative effects of a product may not yet be known to the general public. At least in the court system, certain procedures must be followed before documents containing such vital information can be sealed. ${ }^{114} \mathrm{Also}$, if the need later arises and an adequate showing is made, such documents can be later unsealed for the public's perusal. ${ }^{115}$ Such institutional protections are completely lacking in the world of private A.D.R.. Arthur Bryant of Trial Lawyers for Public Justice hits the mark on this important point:

${ }^{108}$ See, e.g., Borzou Daragahi, "Environmental ADR" N.Y.L.J., (8 $8^{\text {th }}$ September, 1994) at p.5; Schroder, supra $\mathrm{n} .53$ at $\mathrm{C} 14$.

${ }_{109}$ See supra $\mathrm{n} .42$ and accompanying text.

110 Robert T. Kenagy, "Whirlpool's Search for Efficient and Effective Dispute Resolutions"

59 Alb. L. Rev. 895 at p. 897 (1995)

111 Ibid at p.898.

112 Ibid.

113 Ibid. Yet another example is the recent Ford-Firestone Tire and S.U.V. debacle.

114 See, e.g., Fed. R. Civ. P. 26(c) (6)-(7) (trade secret material can be sealed "for good cause" as "justice requires")

${ }_{115}$ See Charles A. Wright et al., Federal Practice and Procedure $\$ 2044.1$ ("Modification of Protective Orders"). 


\section{UNCOMMON LAW}

"[S]ecrecy subverts democracy itself... Every day the papers are filled with disputes over whether our civil rights, securities, antitrust, product liability, environmental and other laws need to be changed. Wouldn't it be great if, in order to decide these and similar questions, the public, Congress and the president could actually know the facts?"116

\section{(b) Widening the Gap Between the "Haves" and "Have-Nots"}

In the United States the public supported judicial system has, at least as one of its announced goals, the desire to bridge gaps in resources between the parties and ensure that the proceeding is conducted on a level playing field. A good judge will often look out for the party who may be outmatched by a betterfunded or more talented opponent. If, for example, a young attorney is having difficulty properly framing an important question to a witness during a trial, it is not uncommon for an American judge to suggest a more appropriate question to ask. But with private A.D.R., the participants bargain for and receive something very different. Third party neutrals do not normally assume such a protective role, especially if they were selected from an industry panel. ${ }^{117}$ Many sophisticated businesses and their corporate counsel know this fact and seek to use it to their advantage, primarily through mandatory arbitration clauses. ${ }^{118}$ While private A.D.R is no doubt appropriate for certain disputes, it should not become a corporate tool for further widening the gap between the "haves" and "have-nots" in business." 119

116 Arthur H. Bryant, Letters, A.B.A. J., (June 1998) at p. 10.

117 See Peter F. Blackman, "Arbitration Suit Asserts Constitutional Arguments" Nat'l L.J., $\left(27^{\text {th }}\right.$ February, 1995) at B1 at B2; Richard C. Rueben, "Reforming ADR" Cal. Law.

(February, 1998) at pp.31-33; and Michele Marcucci, "Freeing ADR" Cal. Law. (February, 1998) at p. $29 \& 70-75$.

118 The American securities industry is notorious for doing this. See, e.g., Susan Antilla, "Brokerage Firms Steer Dissatisfied Customers Away From Court, but in Only One Direction" N.Y. Times (12 th May, 1995) at A29.

119 See Marc Galanter, "Why the "Have's" Come Out Ahead: Speculations on the Limits of Legal Change" 9 Law \& Soc'y Rev. 95 (1974) (comparing the structural advantages of institutional litigants to "one-shot" litigants). Galanter notes that institutional litigants are typically those organizations that: (1) engage in frequent litigation; (2) are more concerned with long-range goals than with the outcome of a particular case; and (3) have the political and economic resources necessary to support their larger interests. Ibid at pp.97-104. Galanter argues that businesses are the classic "repeat players" in the legal system and as such, are able to use their experience as "repeat players" to their advantage. Ibid. 


\section{THE DENNING LAW JOURNAL}

\section{(c) A Reduction in the Power and Legitimacy of the Courts}

Courts, like any institution, can only function properly if they have the respect and support of the people. However, as businesses make increasing use of private A.D.R., only certain types of cases may be left in the court system -namely, criminal, family law, civil rights, in pro per cases, and the like -thereby reducing the overall power of the courts in our society. ${ }^{120}$ Is America moving toward a society in which the businesses with money make use of private A.D.R. ${ }^{121}$ while others are consigned to public courts which government will have little incentive to fund because their constituents lack political clout? Will American courts suffer the same fate as its public school system? ${ }^{122}$ Perhaps. Thus, the following admonition by Illinois Supreme Court Justice Moses Harrison should be kept in mind:

"Generally speaking, I'm opposed to dispute resolution and mediation. I know that we need some means to dispose of cases, but I don't believe that sitting around trying to talk things over is an adequate substitute for formal proceedings governed by rules of evidence and presided over by an experienced judge. Our current system is the culmination of centuries of experience, experience which has shown that without rules of evidence, real justice is difficult to achieve. [A.D.R.] may make ... statistics look good, but good statistics don't necessarily reflect an improvement. After all, Mussolini made the trains run on time in Italy, but so what? He had to turn his country into a fascist state to do it. Mediation and alternative dispute resolution proposals are seductive because they promise to reduce costs, but they are

120 See David Luban, "Settlements and the Erosion of the Public Realm" 83 Geo. L. J. 2619 at p.2625 (1995) ("Whenever disputants rely on the final and public judgement of a court to resolve their controversy, they enhance the court's claim as an authoritative resolver of controversies. However, when disputants turn elsewhere for resolution - private arbitration, nonjudicial government agencies, or private bargaining - the salience of adjudication fades and the authority of courts weakens.").

121 See, e.g. Reuben, supra n. 42 at p. 55 (noting that fees charged by private rent-a-judges range from $\$ 350$ to $\$ 500$ per hour). Presumably, only wealthy businesses and litigants can afford such rates, thereby creating a two-tier system of justice - one for the "haves" and another for the "have-nots."

${ }_{122}$ See James Podgers, "Chasing the Ideal: As More Americans Find Themselves Priced Out of the System, the Struggle Goes on to Fulfill the Promise of Equal Justice for All" A.B.A.J., (August, 1994) at p.61 (analogizing the harm to public education due to loss of public support to the potential harm to the public court system if the big players exit the system for private A.D.R.). 


\section{UNCOMMON LAW}

dangerous because they are also a means for reducing the power of the courts. These proposals are in direct competition with our court system. Indeed, they threaten to destroy to very system that is the very basis of our profession. They undermine the judiciary by diverting scarce resources away from the courts and by placing the process under the control of people who do not know and have no reason to know any law or rules of evidence. The result, I believe, will be a cut-rate brand of rough justice that is neither fair nor consistent, but merely cheap."

\section{Proceed With Caution: Are ADR and the Privatization of COMMERCIAL DiSPUTE RESOLUTION IMPORTS ENGLAND NEEDS?}

The continued vitality and utility of a contemporary body of commercial common law in the United States and England, based upon many courts' experiences with similar business cases, and the evolution of a set of principles to govern business conduct, requires: (1) that there continue to be a substantial pool of business cases processed and decided by our respective public court systems; and (2) that the decisions in those cases be available as precedent and become part of the evolving framework for governing and deciding business and commercial disputes.

England \& Wales appear poised at an important juncture in the effort to reform the civil justice system and in particular how A.D.R. should be incorporated in those reforms (if at all). They have been operating under the Woolf reforms for almost two years now and although by comparison with the United States the use of A.D.R. in England \& Wales is quite limited, proposals for reform in England \& Wales increasingly embrace A.D.R. as potentially offering solutions to the problems at least of cost and delay. ${ }^{124}$

Based upon the American experience over the past twenty-five years with civil justice reforms and the authors' own past analyses of reforms which might be implemented in the United States, ${ }^{125}$ we make the following cautionary observations about the advisability and efficacy of incorporating A.D.R. and

123 Justice Moses Harrison, 1996 Illinois Supreme Court dinner keynote address, quoted in Lucille M. Ponte \& Thomas D Cavenagh, Alternative Dispute Resolution in Business (West Educational Pub., 1999) at pp.329-330.

124 See Sally Lloyd-Bostock, "Alternative Dispute Resolution and Civil Justice Reform: Is ADR Being Used to Paper Over Cracks?" 11 Ohio St. J. on Disp. Resol. 397 (1996).

125 See, e.g., Chris A. Carr \& Michael R. Jencks, "A Different Perspective on Privatizing Business Dispute Resolution" TortSource (American Bar Association) (Fall, 1999), at p.4. 
other privatization devices in an English context. Or, as one U.K. commentator succinctly framed it, is institutionalized A.D.R. "an import we want?"

\section{(a) Maintaining a Sufficient Quantity and Variety of Business Cases}

If the common law is to continue to evolve contemporary principles for allocating risk and deciding business and commercial disputes, the court system must be able to attract and process a large number and variety of business cases. Only with a sufficient number and variety of cases can the system operate to fine-tune itself by recognizing patterns of commercial practice and in turn develop common law responses to recurring problems. ${ }^{127}$

The past two decades have witnessed a number of initiatives in the American court system, a great majority of which single out and attempt to address the issue of delay, that "justice delayed is justice denied." 128 These initiatives have included the so-called "Rocket Docket" and "Fast Track" programmes, as well as increased judicial intervention and management of cases. The extent to which those reforms address and improve the viability and attractiveness of the court system as a form of choice for business cases in unclear.

The reforms based on Lord Woolf's recommendations which were implemented and apply to all claims actions begun on or after $26^{\text {th }}$ April, 1999 , appear to focus on streamlining the process for certain categories of cases and thereby address the issue of delay. ${ }^{129}$ The Woolf reforms apply to four protocols: housing disrepair, medical negligence, road traffic accidents, and personal injury. ${ }^{130}$ These claims are then fitted into three claim tracks: a small claims track involving damages less than $£ 5,000$ for which costs are restricted and a hearing will likely not be required; a fast track, with claims valued up to

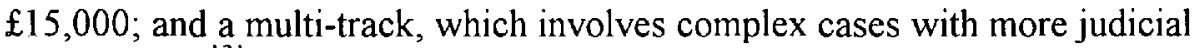
management. ${ }^{131}$ Unlike the American example, the reforms based on Lord Woolf's recommendations at least at this early stage are focused just on those four categories of cases. Those categories, particularly the personal injury

\footnotetext{
126 See Lloyd-Bostock, supra n. 124 at p.397.

127 Earlier it was noted that in the United States only a fraction of cases are resolved by trial Thus, if we assume that ninety-five percent of all business cases are settled or otherwise disposed of before trial, and if, of the remaining five percent, half (or more) are eliminated from the precedent setting pool due to selective publication, vacatur, or depublication, then by the end of the process, very few cases are even left over to grow and develop our contemporary body of commercial common law in a meaningful way.

128 John K. Van de Kamp \& Richard Jacobs, "Reducing Time to Trial: The Trial Court Delay Reduction Act of 1986" I Cal. Litig. 9 at p.9 (1987).

129 See Meder \& Vickers, supra n. 37.

${ }^{130}$ Ibid.

131 Ibid.
} 
category covering road accidents, slip and fall, and employer liability cases, share certain attributes, including relatively high frequency and low severity and are amenable to fast-track treatment. This is a very different situation from the way reforms have generally been implemented in the United States, where fast track and delay reduction rules have been applied generally across the board to cases of all types, and with the possible exception of small claims matters, without significant distinction based upon the amount in controversy. ${ }^{132}$

\section{Just Say No to Institutionalized A.D.R.}

It is undisputed that private consensual A.D.R., particularly arbitration, while sometimes faster and arguably cheaper than full-blown judicial proceedings, has fewer safeguards against error. ${ }^{133}$ For this fact alone, parties who agree to binding arbitration or are often deemed to have accepted the increased risk of error inherent in their chosen system. But for courts to broadly institutionalize and mandate arbitration, even where not binding and de novo review is possible, as a pre-condition to having a matter tried in court (as is the most frequent iteration in American reforms), is fundamentally at odds with the consensual nature of arbitration and the fact that arbitration is and should remain a matter of contract. As discussed above, the fact that arbitrators are not public officers and are in no way publicly accountable, that the proceedings takes place in private, are subject to no or only minimal appellate review, and generally limit or prohibit discovery, ${ }_{2}^{134}$ all militate against compelling arbitration. Finally, as other commentators have noted with respect to the current A.D.R. proposals in the U.K., it remains to be seen how the introduction of A.D.R. procedures will actually improve access to justice.

"It will be unfortunate if reducing court delays and costs to the public purse are viewed as automatically improving access to justice, and if concerns over cost lead to the introduction of ADR procedures that worsen problems they are ostensibly intended to cure."

\footnotetext{
132 In some states, for example, California, judicially mandated arbitration is limited to cases where the amount in controversy, exclusive of interest and fees, is less than $\$ 50,000$. See California Rule of Court 1600.5

${ }^{133}$ See discussion in Moncharsh v. Heily \& Blase, 3 Cal. $4^{\text {th }} 1$ at $7-28 ; 832$ P.2d 899 at $902-$ 915; 10 Cal. Rptr. 2d 183 (1992)

134 See Broughton, supra n.34 at 1082: 78.

135 See Lloyd-Bostock, supra n. 124 at p.402.
} 


\section{THE DENNING LAW JOURNAL}

\section{If Institutionalized A.D.R. is Adopted it Should Be Limited to Appropriate Cases}

In the event that the current enthusiasm for embracing A.D.R. and building it into civil procedure proves unavoidable, it should, for the reasons discussed in this article including the impact on the development of the common law and its generally inferior quality of justice, be limited to categories of claims which demonstrate high frequency, low severity, modest damages, and where time is of the essence. So limited, A.D.R. will at least have a chance to realize some of its promise of efficiency in modest cases and the fact that the high frequency, low severity cases are likely to be ones which do not generally involve quicklyevolving areas of law or business and which might not be expected to be hotbeds for the evolution of new principles through the mechanisms of common law courts.

\section{Limit Voluntary Arbitration to Protect Legitimate Public Interests and Avoid Inherent Conflict}

In the United States, civil justice reforms have generally resulted in private consensual arbitration being given virtually a blank check and the courts bending over backwards to see that such arbitration agreements are not just observed but indulged. Voluntary arbitrations are of particular interest to the subject of this article because it can be anticipated that many of them will represent business disputes. The ability of parties to contractually agree to arbitrate their disputes should have some reasonable limitations when those disputes affect the public interest. For example, anti-waiver provisions may be useful in insuring that statutes meant to protect the public and consumers or which provide for injunctive relief, are not in a wholesale fashion relegated to the private, unreviewable, unaccountable universe of arbitration. Interestingly, in the United States it is only recently that courts have begun understanding that there may be inherent conflicts between arbitration and the underlying legislative purposes of certain enforcement and injunctive relief remedies and that:

"the judicial forum has significant institutional advantages over arbitration in administering a public injunctive remedy, which as a consequence will likely lead to the diminution or frustration of the public benefit if the remedy is entrusted to arbitrators." 136

Another important area where there is a public interest in proscribing private arbitration is in connection with the scope of judicial review. In the courts'

${ }^{136}$ See Broughton, supra n. 34 at 1082 . 
eagerness to reduce their caseloads and the resulting affection for giving arbitration the benefit of any doubt, many courts have effectively abdicated any role in judicial review of arbitration awards, even being willing to confirm arbitration awards they know to be manifestly wrong and substantially unjust. ${ }^{137}$ There is a public interest which should be asserted by the courts that if an arbitration award on its face is erroneous and on its face results in substantial injustice, a court asked to confirm the award:

"will not turn a blind eye to the consequences of its action, but will instead take the only course consistent with its fundamental mandate, and will vacate the award."138

To hold otherwise not only undermines the courts' fundamental objective and goal which must be justice, but it also effectively would allow the exercise of judicial power to be controlled or compelled by private agreement or stipulation, which is equally anathema to a system dedicated to justice. Accordingly, even on cases which proceed to private arbitration, the court should insist on a standard of review that will allow the correction of gross error that results in a substantial injustice.

\section{(b) Insuring the Availability and Use of Decisions}

As discussed above, the second thrust of American reforms has been to encourage procedures which have the result of rendering court decision's useless as a precedent or principles for reference or guidance in future disputes. These procedures including vacatur, selective publication, no citation rules and depublication operate to withdraw from the pool of accumulated wisdom and experience a body of cases and make them inaccessible for use in evolving the common law. Furthermore, the very nature of the self-selection process inherent in most of the procedures and of allowing a court to decide whether a particular decision or opinion may or should be used for guidance or precedent in another time, is inherently flawed. ${ }^{139}$ We would urge that English reformers resist the

\footnotetext{
137 See, e.g., Moncharsh, supra n. 133

${ }_{138}$ Moncharsh, ibid at 832 P.2d at 921

139 One of the authors previously represented a petitioner before the United States Supreme Court in which certiori was granted from a unanimous United States Circuit Court of Appeal decision against him, and which was also deemed "not for publication." The case before the Supreme Court, which involved the scope of federal jurisdiction under Section 2 of the Constitution, was reversed by a unanimous Supreme Court, leaving the decision by the Circuit Court not to publish its decision, as a curious substantive and procedural anomaly. Indeed, the author who represented the petitioner in the case, which has since been cited
} 
temptation to allow workload concerns to justify these peculiar American inventions which so undermine the presumption of the common law and privatize the resolution of the dispute. Selective publication, vacatur and depublication should be barred and rules put in place to permit the citation of any decision by an appellate court of record. Not only would this be consistent with the traditional common law model, ${ }^{140}$ but in this age of computers there can be no reasonable objection made to the burden or expense of making available all decisions of appellate courts of record.

\section{IX.Conclusion}

Civil justice reform initiatives need to be sensitive to the fact that our court systems have a function and purpose beyond just resolving as quickly as possible and at the lowest cost the immediate dispute before them. Those of us who were raised in and who cut our teeth on the common law tradition tend to take the common law for granted; after all it has survived many challenges over the past hundreds of years. But we submit that even well-intentioned reforms attempting to serve the goals of cost savings and reduction in court caseloads, which have the effect of diverting significant numbers of commercial cases from the public courts and/or which impair the ability to refer to and use precedent and past decisional authority in fashioning solutions to new problems will not only reduce the collective experience and wisdom available and embodied in the common law but "conflict with other goals not the least of which is justice." manifest demonstration of necessity and not casually as simply the reform flavour in vogue this month. As we look to the future of business dispute resolution in the $21^{\text {st }}$ century featuring challenges of e-commerce and increased globalization, among others, we would do well to respect and safeguard the genius and vital contribution of the living common law. It is hoped that England $\&$ Wales might avoid and learn from some of the missteps and results of the United States civil justice reform experience. There are signs, for example in the relatively limited and defined protocols in the categories of cases affected by the Woolf reforms, that England \& Wales are proceeding more cautiously than we did and, as a result, that courts in England \& Wales remain and are likely to continue to remain, an important, attractive and efficient institution in promoting justice in its citizens' business and commercial lives.

hundreds of times, continues to get queries about where other lawyers and scholars can find the Circuit Court's opinion.

${ }_{140}$ See Carpenter, supra n.73 at p. 240.

141

See Lloyd-Bostock, supra n. 124 at p.401 


\section{UNCOMMON LAW}

Francis Bacon observed that:

"[h]ad it not been for Sir Edward Coke's Reports ... the law by this time had been almost like a ship without ballast, for that the cases of modern experience are fled from those that are adjudged and ruled in former time."

To provide that ballast and continuity without stasis is the unique gift of the common law. As Australia's High Court Justice, Michael Kirby, has explained:

"the element of creativity, properly harnessed and well directed, is not a weakness of the common law system. It is a mighty strength. It helps to explain the survival of the common law as one of the greatest of the legacies of the British Empire. It helps to avoid stamping, unquestioned, on one generation, the morality, attitudes and social rules of the distant past."

142 Francis Bacon, quoted in Bowen, supra n. 2 at p.507.

143 The Hon. Justice Michael Kirby, supra n.8 at p. 145. 